\title{
The Relation between Science Student Teachers' Approaches to Studying and Their Attitude to Reflective Practice
}

\author{
Rifat Efe ${ }^{1}$ \\ ${ }^{1}$ Ziya Gokalp Education Faculty, Dicle Univerity, Diyarbakir, Turkey \\ Correspondence: Rifat Efe, Ziya Gokalp Education Faculty, Department of Biology Education, 21280 Sur, \\ Diyarbakir, Turkey. E-mail: rifatefe@dicle.edu.tr
}

Received: December 1, 2017

Accepted: January 12, $2018 \quad$ Online Published: March 28, 2018

doi:10.5539/ies.v11n4p54

URL: https://doi.org/10.5539/ies.v11n4p54

\begin{abstract}
In this study, the relation between science student teachers' approaches to studying and their attitude to reflective practice were investigated. The participants were 345 science student teachers on teacher education course during 2015-2016 academic year. The data was collected through Approaches and Study Skills Inventory for Students (ASSIST) and Student Teachers Attitude to Reflective Practice questionnaires. Pearson correlations and multiple regressions were used to analyse the data. The study found that the participant science student teachers' approaches to studying were significant predictors for their attitude to reflective practice. The findings have important implications for student teachers' professional development while they are training to become teachers.
\end{abstract}

Keywords: approaches to studying, reflective practice, student teachers, teacher education

\section{Introduction}

The way students prefer to study has increasingly gained attention from educational researchers as knowing how individual prefers to learn help teachers to organise the learning environment in the best possible way to enhance student learning (Duff \& Mladenovic, 2015; Nordin, Abdul Wahab, \& Dahlan, 2013; Senemoglu, 2011). Different approaches have emerged through identifying student differences in the learning process. Some students show deep interest in the content being studied and related this content to the previous learnt, while some try memorise the content without intending for meaning (Biggs, 1999). This has been used to describe why some students are more successful in teaching learning process than the others (Biggs, 2001). In traditional learning environment where teachers are the source of knowledge and students the passive recipient students tend to learn by a surface approach (Dart, Burnett, \& Purdi, 2000). Whereas, in the learning environments where students actively participate, critically approach to the material and take responsibility for learning, deep approach to learning are experienced (Pimparyon et al., 2000).

An approach to studying includes an individual's preferred way when faced with a new situation, learning new knowledge, preparing for a challenging duty or reviewing the old knowledge in a subject (Entwistle, McCune, \& Hounsell, 2003; Entwistle \& McCune, 2004; Ballantine, Duff, \& McCourt-Larres, 2008). Approaches to studying have important impact on an individual's educational process. Students' awareness for their best suitable way of studying result in their preference when learning individually or during the teaching/learning process (Biggs, 2001). An individual's success in reaching the learning goals as much as possible as a result of a certain studying approach defies the effectiveness of the studying approach (Entwistle \&McCune, 2004). The persistence and continuity in successful outcome has an impact on effective studying. An effective instructional planning includes considering the preferred studying way by the learners. Teachers' awareness for effective studying preferences displayed by learners and inclusion of this in classroom activities enhances the successful outcomes for learning aims. A studying approach includes the variation in aims and activities when performing a learning process. The way students perform learning task and the degree they are affected by the environment show a decisive effect on the learning product (Ekinci, 2015). A learning approach defined as the variety of the appropriate learning activities can be selected for the learning process (Entwistle \& McCune, 2004). Studies have demonstrated that differences in the learning environments affect the preference of a certain studying approach (Colak \& Fer, 2007; Acisli, 2015). In the traditional learning environments where teachers act as the source of knowledge students usually are usually faced with rote learning. In these situations, students incline toward surface learning (Dart, Burnett, \& Purdi, 2000). In contrast in the learning environments, where students have their own responsibility for 
learning, they are encouraged for critical thinking and problem solving as deep or meaningful learning occurs (Pimparyon et al., 2000). In this kind of environment knowing a students' preference for studying guides the teacher for an effective organisation of the learning process (Vermetten, Lodewijks, \& Vermunt, 1999). A student's perception of the academic environment is an important factor for preferring a certain way of studying (Richardson, 2011). It is suggested that students develop different approaches for studying for different subjects and topics (Entwistle \&McCune, 2004). Learning environment, assessment, teaching quality or the teachers' role affect a student's approach for studying (Vermetten, Lodewijks, \& Vermunt, 1999). Studies reveal that promoting deep learning and trying to prevent surface learning lead to a fruitful learning environment (Ozan, Kose, \& Gundogdu, 2012). Students' studying approaches are informative for the quality and effectiveness of instruction used in the learning process (Biggs, 1999). That is because the learning process is realised by the interactions of different element such as students' activities, teacher's activities, teaching materials, works, activities (Biggs, Kember \& Leung, 2001). As the teaching learning process is becoming individualised with fast changes in education, identifying an individual's preferred studying approach seen as important in order to organise the learning process and environment accordingly. Marton and Saljo (1976) identified two types of approaches to learning; deep and surface. This model was further extended by Entwistle (1979) by adding a third approach called strategic. Entwistle (2000) described different behaviours displayed by students while learning as approaches to studying. According to this model student use deep, strategic or surface approach to studying. Deep approach includes looking for meaning, connecting ideas, using evidence and interest for ideas. Students adopting deep approach display an active engagement in their learning, intend to understand the material by critically relating the meaning to the other experiences and ideas (Nordin et al., 2013), show interest in their studies (Senemoglu, 2011) and are intrinsically motivated (Biggs, 2003). Strategic approach involves organising studying, time management and being sensitive to evaluation needs. In strategic approach, students' main aim is to achieve the highest possible grades through organized study methods (e.g. using previous exam papers to predict questions, be alert to cues about marking schemes) and time-management skills (Entwistle \& Ramsden, 1983). The surface approach includes not being aware of the aims, memorisation of disconnected parts, curriculum oriented and anxiety for failure. Individuals who prefer surface approach rely on rote-learning and memorisation without looking for connection with other ideas (Duff \& Mladenovich, 2015).

As teacher education institutions increasingly attempt to connect theory with practice during student teachers' professional development, reflection or being able to reflect becomes an inseparable part of teacher education programs (Harrison et al., 2005; Buschor \&Kamm, 2015). Reflection is defined as the critical analysis and evaluation of the process of learning or practice that the individual engaged in (Black \& Plowright, 2010). During this practice student teachers assess the origins, purposes, and consequences of their work in a regular manner (Buschor \& Kamm, 2015). Different types of reflection have been identified over the years by the researcher working in the field. Shon (1987) distinguished between reflection in action and reflection on action. Reflection in action refers taking or being aware of decisions in situations while teachers are still in the process of teaching. In contrast reflection on action refers to a teachers' critique on his practice after the practice finished. New approaches toward student teachers' competence development have led to the identification different level of reflection. Hatton and Smith (1995) suggested three levels, descriptive, dialogic and critical, of reflection on action and four levels, technical, descriptive, dialogic and critical, of reflection in action. Descriptive level includes student teachers seeking what is seen as "best possible" practice. Weighing competing claims and viewpoints, and then exploring alternative solutions is described as dialogic. Drawing from a given research/theory base, but always interpreted in light of personal worries and previous experience is categorised as technical and seeing as problematic, according to ethical criteria, the goals and practices of one's profession is described as critical. Student teachers' approaches to learning are important as it gives evidence for means and ways they prefer while engaged in the learning process. Likewise, reflective practice as considered as a crucial part of student teachers' professional development. Taking these as the base, this study looked whether science student teachers' study approaches can be predictor for their attitude toward reflective practice. In order to realise this aim, the following research questions were investigated:

1) Is there any correlation among the three approaches to studying and student teachers attitude to reflective practice?

2) Can science student teachers' deep, strategic and surface approaches to studying be predictors for science student teachers' attitude to reflective practice and the nature of teaching?

3) Can science student teachers' deep, strategic and surface approaches to studying be predictors for science student teachers' attitude to reflective practice and professional development?

4) Can science student teachers' deep, strategic and surface approaches to studying be predictors for science 
student teachers' attitude to reflective practice and teacher education?

\section{Methodology}

\subsection{Participants}

Science student teachers participated in the study were on teacher education course at Ziya Gokalp Education Faculty, Dicle University, during 2015/16 academic year. In total, 345 (M: 91, F: 254) science student teachers majoring in biology (n: 155), chemistry (n: 115) and primary science (n: 115) participated in the study.

Table 1. The number of science student teachers participated in the study according to grades

\begin{tabular}{lccc}
\hline & Biology & Chemistry & Primary science \\
\hline Grade 1 & 23 & 22 & 23 \\
Grade 2 & 23 & 23 & 23 \\
Grade 3 & 23 & 23 & 23 \\
Grade 4 & 23 & 23 & 23 \\
Graduated- on short teacher education course & 35 & 35 & None \\
\hline
\end{tabular}

In table 1 science student teachers' participation based on their year of study is provided. The undergraduate course for teacher education last for four years. There are also who already graduated from a science subject (e.g. biology, physics and chemistry) and enroll on one year long teacher education course before being able to teach in the schools.

\subsection{Data Collection Instruments}

In the study Approaches and Study Skills Inventory for Students (ASSIST) was used to collect the data for science student teachers approaches to studying and Science Student Teachers' Attitude to Reflective Practice questionnaire was used to collect the data science student teachers' attitude to reflective practice. The ASSIST was developed by Tait, Entwistle, and McCune (1998) and translated into Turkish by Senemoglu (2011). It contains sections related to student approaches to studying, student's definition of concept of learning and preferences for different types of courses and teaching. In this study, the section included student approaches to studying were used to collect the data. In contains 52 statements divided by subscales; deep, strategic and surface approaches. For the translated version of the ASSIST a confirmatory factor analysis was performed and the model produced fit indices to fit the original model $(\mathrm{CFI}=97, \mathrm{NNFI}=97, \mathrm{RMSEA}=0.03)$ with a Cronbach's Alpha value of 0.81 (Senemoglu, 2011).

The science student teachers' attitude to reflective practice was developed by (Efe, 2009). It comprises of 23 items and three subscales; reflective practice and teacher education ( 7 items), reflective practice and nature of teaching (8 items) and reflective practice and professional development (8 items). For this study, the Cronbach's Alpha value was .842 for the whole scale. Cronbach's Alpha value for the first factor was .824 , for the second factor was .768 and for the third factor was .813. Both instrument included a five- point Likert type scale that required science student teachers to respond to the items either as "strongly disagree", "disagree", "no opinion", "agree", "strongly agree".

\subsection{Data analysis}

The data analysis was done by using SPSS 25. Pearson correlation was performed to look for the correlations among the six subscales, deep, strategic, surface approaches and reflective practice and teacher education, reflective practice and nature of teaching, reflective practice and professional development. Multiple regression analysis was carried out to examine whether science student teachers' approaches to had have any effect on science student teachers' attitude to reflective practice.

\section{Results}

In this section, firstly findings of the correlations among the three sub-dimensions of approaches to study, deep, strategic and surface approaches and three sub-dimensions of attitude to reflective practice, reflective practice and the nature of teaching, reflective practice and professional development and reflective practice and teacher education is provided. Secondly, the findings related to multiple regression analysis for deep, strategic and surface approaches to studying as predictors of the three sub-dimensions of reflective practice; reflective practice and the nature of teaching, reflective practice and professional development and reflective practice and teacher education. Also, the findings of a multiple regression analysis to predict whether the three sub-dimensions of study to 
approaches are predictor of student attitude to reflective practice as a whole.

\subsection{Pearson Correlations}

The examination of Pearson correlation indicates a high level of correlation among the six variables used in the study (Table 2). Deep approach to study has a statistically significant positive correlation with strategic approach to study $(\mathrm{r}=.935, \mathrm{p}<.05)$, reflective practice and the nature of teaching $(\mathrm{r}=.753, \mathrm{p}<.05)$, reflective practice and professional development $(\mathrm{r}=.743, \mathrm{p}<.05)$ and reflective practice and teacher education $(\mathrm{r}=.765, \mathrm{p}<.05)$. Also, there is a statistically significant negative correlation between deep approach to study and surface approach to study $(\mathrm{r}=-674, \mathrm{p}<.05)$. In the same vein, the findings revealed that strategic approach to study is strongly related to reflective teaching and the nature of teaching $(\mathrm{r}=.761, \mathrm{p}<.05)$, reflective practice and professional development $(\mathrm{r}=.736, \mathrm{p}<.05)$ and reflective practice and teacher education $(\mathrm{r}=.757, \mathrm{p}<.05)$. The analysis of the data shows that strategic approach to studying is negatively related to surface approach to studying $(r=-.688, p<.05)$. Based on the findings, surface approach to teaching is negatively related to reflective practice and the nature of teaching $(\mathrm{r}=-.691, \mathrm{p}<.05)$, reflective practice and professional development $(\mathrm{r}=-.737, \mathrm{p}<.05)$ and reflective practice and teacher education $(\mathrm{r}=-.693, \mathrm{p}<.05)$.

Table 2. Pearson correlation for the six variables

\begin{tabular}{|c|c|c|c|c|c|c|c|c|}
\hline & & & 1 & 2 & 3 & 4 & 5 & 6 \\
\hline \multirow{9}{*}{ 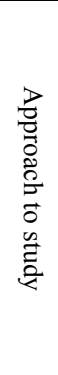 } & \multirow{3}{*}{ Deep } & Pearson Correlation & 1 & $.935^{* *}$ & $-.674^{* *}$ & $.753^{* *}$ & $.743^{* *}$ & $.765^{* *}$ \\
\hline & & Sig. (2-tailed) & & .000 & .000 & .000 & .000 & .000 \\
\hline & & $\mathrm{N}$ & 345 & 345 & 345 & 345 & 345 & 345 \\
\hline & \multirow{4}{*}{ Strategic } & Pearson Correlation & $.935^{* *}$ & 1 & $-.688^{* *}$ & $.761^{* *}$ & $.736^{* *}$ & $.757^{* *}$ \\
\hline & & Sig. (2-tailed) & .000 & & .000 & .000 & .000 & .000 \\
\hline & & $\mathrm{N}$ & 345 & 345 & 345 & 345 & 345 & 345 \\
\hline & & Pearson Correlation & $-.674^{* *}$ & $-.688^{* *}$ & 1 & $-.691^{* *}$ & $-.737^{* *}$ & $-.693^{* *}$ \\
\hline & \multirow[t]{2}{*}{ Surface } & Sig. (2-tailed) & .000 & .000 & & .000 & .000 & .000 \\
\hline & & $\mathrm{N}$ & 345 & 345 & 345 & 345 & 345 & 345 \\
\hline \multirow{9}{*}{ 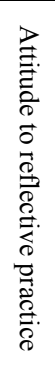 } & \multirow{3}{*}{$\begin{array}{l}\text { Reflective practice and } \\
\text { the nature of teaching }\end{array}$} & Pearson Correlation & $.753^{* *}$ & $.761^{* *}$ & $-.691^{* *}$ & 1 & $.839^{* *}$ & $.844^{* *}$ \\
\hline & & Sig. (2-tailed) & .000 & .000 & .000 & & .000 & .000 \\
\hline & & $\mathrm{N}$ & 345 & 345 & 345 & 345 & 345 & 345 \\
\hline & \multirow{3}{*}{$\begin{array}{c}\text { Reflective practice and } \\
\text { professional } \\
\text { development }\end{array}$} & Pearson Correlation & $.743^{* *}$ & $.736^{* *}$ & $-.737^{* *}$ & $.839^{* *}$ & 1 & $.825^{* *}$ \\
\hline & & Sig. (2-tailed) & .000 & .000 & .000 & .000 & & .000 \\
\hline & & $\mathrm{N}$ & 345 & 345 & 345 & 345 & 345 & 345 \\
\hline & \multirow{3}{*}{$\begin{array}{l}\text { Reflective practice and } \\
\text { teacher education }\end{array}$} & Pearson Correlation & $.765^{* *}$ & $.757^{* *}$ & $-.693^{* *}$ & $.844^{* *}$ & $.825^{* *}$ & 1 \\
\hline & & Sig. (2-tailed) & .000 & .000 & .000 & .000 & .000 & \\
\hline & & $\mathrm{N}$ & 345 & 345 & 345 & 345 & 345 & 345 \\
\hline
\end{tabular}

The findings suggest all six variables are correlated to each other, which means the increase or decrease in one variable affect the other variables used in the study. Science student teachers preferred deep and strategic approaches to studying were likely to have a high attitude to reflective practice and the nature of teaching, reflective practice and professional development and reflective practice and teacher education. The participant science teachers who preferred surface approach to studying were more likely to a low attitude to reflective practice and the nature of teaching, reflective practice and professional development and reflective practice and teacher education. After these high correlations among the sub-dimensions of student teachers' approaches to study and the participant science student teachers attitude to the sub-dimensions of reflective practice, a multiple regression was carried out to how important were deep, strategic and surface approaches as predictors for reflective practice and the nature of teaching, reflective practice and professional development and reflective practice and teacher education.

\subsection{The Effect of Approaches to Studying On Attitude to Reflective Practice and the Nature of Teaching}

A multi linear regression was calculated to predict science student teachers' attitude to the nature of teaching and reflective practice based on their deep, strategic and surface approach to studying. A significant regression equation was found $(\mathrm{F}(3.341)=202.625), \mathrm{p}<.000$ with an $\mathrm{R}^{2}$ of .637 (Table 3). Participants' predicted attitude to the nature of teaching and reflective practice is equal to 2.244-0.225 (surface approach) +0.247 (deep approach) +0.290 (strategic approach). 
Table 3. The effect of approaches to studying on student attitude to reflective practice and the nature of teaching

\begin{tabular}{lccccccc}
\hline & $\mathrm{B}$ & Std. Error & Beta & $\mathrm{t}$ & $\mathrm{S}$ Sig. & Zero-order & Partial \\
\hline Constant & 2.244 & .246 & & 9.109 & .000 & - & - \\
Strategic & .290 & .088 & .310 & 3.311 & .001 & .761 & .176 \\
Surface & -.225 & .033 & -.302 & -6.709 & .000 & -.691 & -.341 \\
Deep & .247 & .087 & .260 & 2.828 & .005 & .753 & .151 \\
\hline $\mathrm{R}=0.800$ & $\mathrm{R}^{2}=637$ & & & & & & \\
$\mathrm{~F}(3.341)=202.625$ & $\mathrm{P}<.000$ & & & & & & \\
\hline
\end{tabular}

Participants' attitude to the nature of teaching and reflective practice increased by 0.247 and 0.290 points for each point of deep and strategic approaches to studying. But participants' attitude to the nature of teaching and reflective practice decreased 0.225 point for each point of surface approach to teaching. All three approaches, deep, strategic and surface, were significant predictors of participant science student teachers' attitude to the nature of teaching and reflective practice.

\subsection{The Effect of Approaches to Studying on Attitude to Reflective Practice and Professional Development}

A multi linear regression was calculated to predict science student teachers' attitude to professional development and reflective practice based on their deep, strategic and surface approach to studying. A significant regression equation was found $(\mathrm{F}(3.341)=217.922), \mathrm{p}<.000$ with an $\mathrm{R}^{2}$ of .657 (Table 4).

Table 4. The effect of approaches to studying on student attitude to reflective practice and professional development

\begin{tabular}{lccccccc}
\hline & $\mathrm{B}$ & Std. Error & Beta & $\mathrm{t}$ & $\mathrm{Sig}$. & Zero-order & Partial \\
\hline Constant & 2.912 & .235 & & 12.380 & .000 & - & - \\
Strategic & .116 & .084 & .127 & 1.390 & .165 & .736 & .075 \\
Surface & -.305 & .032 & -.420 & -9.531 & .000 & -.737 & -.459 \\
Deep & .317 & .083 & .342 & 3.812 & .000 & .743 & .202 \\
\hline $\mathrm{R}=0.811$ & $\mathrm{R}^{2}=657$ & & & & & & \\
$\mathrm{~F}(3.341)=217.922$ & $\mathrm{P}<.000$ & & & & & & \\
\hline
\end{tabular}

Science student teachers' predicted attitude to professional development and reflective practice is equal to 2.912-0.305 (surface approach) +0.317 (deep approach) +0.116 (strategic approach).

Science student teachers' attitude professional development and reflective practice increased by 0.317 and 0.116 points for each point of deep and strategic approaches to studying. But participants' attitude to professional development and reflective practice decreased 0.225 point for each point of surface approach to teaching. While deep and surface, were significant predictors of participant science student teachers' attitude to professional development and reflective practice (Table 4). Strategic approach to studying did not appeared as a statistically significant predictor of science student teachers' attitude to professional development and reflective practice $(\mathrm{p}>.05)$

\subsection{The Effect of Approaches to Studying on Attitude to Reflective Practice and Teacher Education}

A multi linear regression was calculated to predict science student teachers' attitude to teacher education and reflective practice based on their deep, strategic and surface approach to studying. A significant regression equation was found $(\mathrm{F}(3.341)=209.016), \mathrm{p}<.000$ with an $\mathrm{R}^{2}$ of .648 (Table 5).

Table 5. The effect of approaches to studying on student attitude to teacher education and reflective practice

\begin{tabular}{lccccccc}
\hline & $\mathrm{B}$ & $\mathrm{Std}$ Error & Beta & $\mathrm{t}$ & Sig. & Zero-order & Partial \\
\hline Constant & 2.420 & .230 & & 10.514 & .000 & \\
Strategic & .167 & .082 & .189 & 2.037 & .042 & .757 \\
Surface & -.213 & .031 & -.304 & -6.822 & .000 & -.693 & .110 \\
Deep & .344 & .081 & .384 & 4.220 & .000 & .765 & \\
\hline $\mathrm{R}=0.805$ & $\mathrm{R}^{2}=648$ & & & & & \\
$\mathrm{~F}(3.341)=209.016$ & $\mathrm{P}<.000$ & & & & & \\
\hline
\end{tabular}


Science student teachers' predicted attitude to teacher education and reflective practice is equal to $2.420-0.213$ (surface approach) +0.344 (deep approach) +0.167 (strategic approach). Science student teachers' attitude to teacher education and reflective practice increased by 0.344 and 0.167 points for each point of deep and strategic approaches to studying. But the participants' attitude to teacher education and reflective practice decreased 0.213 point for each point of surface approach to teaching. While all three approaches, deep, strategic and surface, were significant predictors of participant science student teachers' attitude to teacher education and reflective practice (Table 5). Strategic approach to studying was statistically a less strong predictor for students' attitude to teacher education and reflective practice sub dimension of the attitude to reflective practice.

\subsection{The Effect of Approaches to Studying on Attitude to Reflective Practice}

A multi linear regression was calculated to predict science student teachers' attitude to reflective practice based on their deep, strategic and surface approach to studying. A significant regression equation was found $(\mathrm{F}(3.341)$ $=701.700$ ), $\mathrm{p}<.000$ with an $\mathrm{R}^{2}$ of .726 (Table 6). Participants' predicted attitude to the nature of teaching and reflective practice is equal to $2.537-0.249$ (surface approach) +0.305 (deep approach) +0.187 (strategic approach)

Table 6 . The effect of approaches to studying on student attitude to reflective practice

\begin{tabular}{lccccccc}
\hline & $\mathrm{B}$ & $\mathrm{Std}$. Error & $\mathrm{Beta}$ & $\mathrm{t}$ & $\mathrm{S}$ Sig. & Zero-order & Partial \\
\hline Constant & 2.537 & .197 & & 12.862 & .000 & & \\
Strategic & .187 & .070 & .217 & 2.661 & .008 & .796 & .143 \\
Surface & -.249 & .027 & -.365 & -9.271 & .000 & -.750 & -.449 \\
Deep & .305 & .070 & .350 & 4.368 & .000 & .799 & .230 \\
\hline $\mathrm{R}=0.852$ & $\mathrm{R}^{2}=726$ & & & & & \\
$\mathrm{~F}(3.341)=301.700$ & $\mathrm{P}<.000$ & & & & & & \\
\hline
\end{tabular}

Participants' attitude to the nature of teaching and reflective practice increased by 0.305 and 0.187 points for each point of deep and strategic approaches to studying. But participants' attitude to the nature of teaching and reflective practice decreased 0.187 point for each point of surface approach to teaching. All three approaches, deep, strategic and surface, were significant predictors of participant science student teachers' attitude to the nature of teaching and reflective practice.

\section{Discussions}

The study investigated the correlations among the participant science student teachers' deep, strategic and surface approaches to studying and their attitude to the subscales of reflective practice used in the study. Previous studies have documented correlations between study approaches and self- efficacy (Gordon \& Debus, 2002; Ekinci, 2015), epistemological beliefs (Cano, 2005), academic performance (Diseth, 2007) perception of academic quality (Lawless \& Richardson, 2002) and procrastination (Akar, 2016). Also, the research in the field investigated the differences between groups such as gender, subjects, age, grade in their approaches to studying (Yilmaz \& Orhan, 2011; Altun, 2013; Olpak \& Korucu, 2014). But it is very rare to come across researches that study the relation of study approaches to reflective practice. The present study found a significant level of correlation among the three subscales of approaches to studying and the subscales of attitude to reflective practice that included reflective practice and the nature of teaching, reflective practice and professional development and reflective practice and teacher education. The findings of the study suggest that science student teachers using deep and strategic approaches to studying are very likely to have a positive attitude toward reflective practice. In contrast science student teachers displaying a surface approach to studying have a high possibility for a lower attitude to reflective practice. The findings are in line with the evidence provided from the previous research that associates the stages of reflection on practice and approaches to learning (Leung \& Kember, 2003; Phan, 2006). Reflective practice is increasingly becoming an important element of developing student teachers for thinking critically and acting on their practice during the teaching process. Developing positive student teachers' attitude to reflection is important as an attitude is usually seen as the predictor of the practice. As the study approaches are associated with positive attitude to reflection, it is important to provide opportunities for student teachers to particularly develop deep and strategic approaches to studying.

The finding of the study available through multiple regression shows that deep, strategic and surface approaches to studying can be significant predictors of science student teachers' attitude to reflective practice and the nature of teaching which included items such as "The work-a-day of a teacher depends upon tacit knowing-in-action", "Every competent teacher can recognise the phenomena for which s/he cannot give a reasonably accurate or 
complete description", "In teaching, there are no rules to follow. The individual has to find his/her own way through", "Any methodology is valuable provided the individual is committed to it "and "Teaching is easier when we have ready-made answers to problems and deliberation is replaced by rule-following". This is valuable because knowing that promoting deep and strategic approaches to studying contribute to the development of positive attitude to reflection and the nature of teaching, teacher educators can focus on providing environments for student teachers when they are looking for opportunities to develop student teachers' reflection skills. The study also revealed that while deep and surface approaches appeared as the predictors of science student teachers' attitude to professional development and reflective practice, surface approach to study did not seemed as a significant predictor. The items such as "Teacher development is something that can only be done by and for oneself.", "professional practice values action itself rather than the outcomes of the action", "Teachers should take responsibility for their own professional development" and "Teachers should reflect on their professional performance not only when things go wrong but also when they go well" do not seem to be the priority of science student teachers who prefer strategic approach to studying. These findings are supportive of the previous studies that individuals resort to strategic approach to studying tends to focus on time management and be sensitive to the evaluation needs (Senemoglu, 2011; Nordin et al., 2013).

Although the findings of the study suggest that all three approaches to studying are significant predictors of science student teachers' attitude to reflective practice and teacher education which included the items such as "since teaching is a craft, it is best learned by working with teachers in classrooms.", "a model of training which relates "perceived knowledge" (factual information and advice) to "experiential knowledge" (trainee's own experiencee.g., during teaching practice) will also encourage teacher development", "Teaching practice has valuable complementary contribution to make to the initial teacher training programme "and "Practical knowledge is the essence of a teacher training course" the participant science students preferred deep approach to studying had more positive attitude to reflective practice and teacher education. Despite the lack of enough evidence in the literature relating study approaches to reflective practice in general, few studies have documented that student teachers who use deep approach to studying which involves organised study habits and deep level of understanding constantly reflects on their practice as they connect the previous knowledge with the new knowledge (Tsingos, Bosnic- Anticevich \&Smith, 2015; Leung \& Kember, 2003; Phan, 2006; Phan, 2007). Reflection can help individuals to develop high order skills such as critical thinking, problem solving and analysing (Phan, 2007) and if the aim of teacher educators to develop student teachers who are aware of their own values and beliefs, able to analyse their own practice (Calderhead \& Gates, 1993) then fostering deep approach to learning becomes important.

\section{References}

Acisli, S. (2015). Investigation of teacher candidates' learning styles and critical thinking dispositions, Necatibey Faculty of Education .Electronic Journal of Science \& Mathematics Education, 9(1), 23-48.

Akar, H. (2016). Analysis the relationship between general procrastination and studying approach of prospective teachers at department of elementary education through structural equation modelling, Sosyal Bilimler Dergisi, 6(11), 111-135.

Altun, S. (2013). An investigation of prospective teachers' approaches to studying according to type of university, major, and gender. Journal of Research in Education and Teaching, 2(2), 227-233.

Ballantine, J. A., Duff, A., \& McCourt-Larres, P. (2008). Accounting and business students' approaches to learning: A longitudinal study. Journal of Accounting Education, 26(4), 188-201. https://doi.org/10.1016/j.jaccedu.2009.03.001

Biggs, J. (1999). Teaching for quality learning at university. London: Open University Press.

Biggs, J. (2001). The reflective institution assuring and enhancing the quality of teaching and learning. Higher Education, 41, 221-238. https://doi.org/10.1023/A:1004181331049

Biggs, J., Kember, D., \& Leung, D. (2001). The revised two-factor Study Process Questionnaire: R-SPQ-2F. British Journal of Educational Psychology, 71, 133-149. https://doi.org/10.1348/000709901158433

Black, P. E., \& Plowright, D. (2010). A multi-dimensional model of reflective learning for professional development. Reflective Practice, 11(2), 245-259. https://doi.org/10.1080/14623941003665810

Buschor, C. B., \& Kamm, E. (2015). Supporting student teachers' reflective attitude and research-oriented stance. Educational Research for Policy and Practice, 14(3), 231-245. https://doi.org/10.1007/s10671-015-9186-z

Calderhead, J., \& Gates, P. (1993). Conceptualizing Reflection in Teacher Development. London, The Falmer 
Press

Cano, F. (2005). Epistemological beliefs and approaches to learning: Their change through secondary school and their influence on academic performance. British Journal of Educational Psychology, 75, $203-221$. https://doi.org/10.1348/000709904X22683

Çolak, E., \& Fer, S. (2007). Öğrenme Yaklaşımları Envanterinin Dilsel Eşdeğerlik, Güvenirlik ve Geçerlik Çalışması'. Çukurova Üniversitesi Sosyal Bilimler Enstitüsü Dergisi, 16(1), 197-212.

Dart, B. C., Burnett, P. C., \& Purdie, N. M. (2000). Students' conceptions of learning, the classroom environment, and approaches to learning. The Journal of Educational Research, 93(4), 262-270. https://doi.org/10.1080/00220670009598715

Diseth, A. (2007). Student evaluation of teaching, approaches to learning and academic performance. Scandinavian Journal of Educational Research, $185-284$. https://doi.org/10.1080/00313830701191654

Duff, A., \& Mladenovich, R. (2015). Antecedents and consequences of accounting students approaches to learning: A cluster analytic approach. The British Accounting Review, 47, 321-338. https://doi.org/10.1016/j.bar.2014.06.003

Efe, R. (2009). Science student teachers attitudes towards reflective practice: differences in subjects and grades. Cypriot Journal of Educational Sciences, 4(2), 72-86.

Ekinci, N. (2015). The relationship between approaches to learning and self-efficacy beliefs of candidate teachers. H.U. Journal of Education, 30(1), 67-76.

Entwistle, N. (2000). Promoting deep learning through teaching and assessment: Conceptual frameworks and educational contexts (Paper presented at TLRP Conference, Leicester, November).

Entwistle, N. J. (1979). Stages, levels, styles or strategies: dilemmas in the description of thinking. Educational Review, 31, 123-132. https://doi.org/10.1080/0013191790310206

Entwistle, N. J., \& McCune, V. (2004). The conceptual base of study strategies inventories in higher education. Educational Psychology Review, 16(4), 325-345. https://doi.org/10.1007/s10648-004-0003-0

Entwistle, N. J., \& Ramsden, P. (1983). Understanding student learning. London: Croon-Helm.

Entwistle, N. J., McCune, V., \& Hounsell, J. (2003). Investigating ways of enhancing university teaching-learning environments: Measuring students' approaches to studying and perceptions of teaching. In E. De Corte, L. Verschael, N. Entwistle, \& J. Van Merrienboer (Eds.), Powerful Learning Environments: Unraveling Basic Components and Dimensions. Amsterdam: Pergamon, Elsevier Science.

Gordon, C., \& Debus, R. (2002). Developing deep learning approaches and personal teaching efficacy within a pre-service teacher education contexts. British Journal of Educational Psychology, 72, 483-511. https://doi.org/10.1348/00070990260377488

Harrison, J. K., Lawson, T., \& Wortley, A. (2005). Mentoring the beginning teacher Developing professional autonomy through critical reflection on practice. Reflective Practice, 6, 419-441. https://doi.org/10.1080/14623940500220277

Hatton, N., \& Smith, D. (1995). Reflection in teacher education: Towards definition and implementation. Teaching and Teacher Education, 11(1), 33-49. https://doi.org/10.1016/0742-051X(94)00012-U

Lawless, C., \& Richardson, J. T. E. (2002). Approaches to studying and perceptions of academic quality in distance education. Higher Education, 44, 257-282. https://doi.org/10.1023/A:1016315114558

Leung, D. Y. P., \& Kember, D. (2003). Te relationship between approaches to learning and refection upon practice. Educational Psychology, 23, 61-71. https://doi.org/10.1080/01443410303221

Marton, F., \& Saljo, R. (1976). On qualitative differences in learning-I: Outcome and Process. British Journal of Educational Psychology, 46, 4-11. https://doi.org/10.1111/j.2044-8279.1976.tb02980.x

Nordin, N., Abdul, R., \& Ainuddin, N. (2013). Approaches to Learning among Trainee Teachers: Malaysian Experiences. Procedia-Social and Behavioral Sciences, 105, $284-293$. https://doi.org/10.1016/j.sbspro.2013.11.030

Olpak, Y. Z., \& Korucu, A. T. (2014). Öğrencilerin ders çalışma yaklaşımlarının farklı değişkenler açısından incelenmesi. Ahi Evran Üniversitesi Kırşehir Eğitim Fakültesi Dergisi, 15(1), 333-347. 
Ozan, C., Köse, E., \& Gündoğdu, K. (2012). Okul öncesi ve sınıf öğretmenliği öğrencilerinin öğrenme yaklaşımlarının incelenmesi. Ĕgitim Bilimleri Araştırmaları Dergisi, 2(2), 75-92.

Phan, H. P. (2006). Examination of student learning approaches, reflective thinking, and epistemological beliefs: A latent variables approach. Electronic Journal ofResearch in Educational Psychology, 10, 577-610.

Phan, H. P. (2007). An examination of reflective thinking, learning approaches, and self-efficacy beliefs at the University of the South Pacific: A path analysis approach. Educational Psychology, 27, 789-806. https://doi.org/10.1080/01443410701349809

Pimparyon, P., Roff, S., McAleer, S., Poonchai, B., \& Pemba, S. (2000). Educational environment, student approaches to learning and academic achievement in a Thai nursing school. Medical Teacher, 22(4), 359-365. https://doi.org/10.1080/014215900409456

Richardson, J. T. E. (2011). Approaches to studying, conception of learning and learning styles in higher education. Learning and Individual Differences, 21, 288-293. https://doi.org/10.1016/j.lindif.2010.11.015

Schon, D. (1987). Educating the reflective practitioner. San Francisco, CA: Jossey-Bass Higher Education Series.

Senemoglu, N. (2011). College of education students' approaches to learning and study skills. Education and Science, 36(160), 65-80.

Tait, H., Entwistle, N. J., \& McCune, V. (1998). ASSIST: a re-conceptualization of the Approaches to Studying Inventory. In C. Rust (Ed.), Improving Students as Learners (pp. 262-271). Oxford:Oxford Brooks University.

Tsingos, C., Bosnic-Anticevich, S., \& Smith, L. (2015). Learning styles and approaches: Can reflective strategies encourage deep learning? Currents in Pharmacy Teaching and Learning, 7(2015), 492-504. https://doi.org/10.1016/j.cptl.2015.04.006

Vermetten, Y. J., Lodewijks, H. G., \& Vermunt, J. D. (1999). Consistency and variability of learning strategies in different university courses. Higher Education, 37, 1-21. https://doi.org/10.1023/A:1003573727713

Yılmaz, M. B., \& Orhan, F. (2011). Ders çalışma yaklaşımı ölçeğinin Türkçe formunun geçerlik ve güvenirlik çalışması. Eğitim ve Bilim, 36(159).

\section{Copyrights}

Copyright for this article is retained by the author(s), with first publication rights granted to the journal.

This is an open-access article distributed under the terms and conditions of the Creative Commons Attribution license (http://creativecommons.org/licenses/by/4.0/). 